\title{
Effect of Azotobacter and Nitrogen Levels on Fruit Yield and Quality of Bell Pepper
}

\author{
Dhruba R. Bhattarai ${ }^{1}$ Krishna P. Poudyal $^{1}$ and Shanta Pokhrel ${ }^{2}$ \\ ${ }^{1}$ Nepal Agriculture Research Council, Khumaltar, Lalitpur \\ ${ }^{2}$ Tri-chandra Multiple Campus Ghantaghar, Kathmandu \\ e-mail: raj01dhruba@gmail.com
}

\begin{abstract}
Inorganic fertilizers alone cannot sustain high levels of productivity. It may cause deterioration of soil environment leading to low productivity. An investigation was carried out to develop integrated nutrient management technology for fruit yield of bell pepper (Capsicum annuum L.). The experiment was conducted at Horticulture Research Division, Nepal Agricultural Research Council Khumaltar, Lalitpur during 2010/011. The experiment was laid out in a randomized block design with three replications and having seven treatments viz., Control (100\% NPK), Azotobacter $+25 \% \mathrm{~N}+\mathrm{PK}$, Azotobacter $+50 \% \mathrm{~N}+\mathrm{PK}$, Azotobacter $+75 \% \mathrm{~N}+\mathrm{PK}$, Azotobacter $+\mathrm{FYM}+25 \%$ $\mathrm{N}+\mathrm{PK}$, Azotobacter $+\mathrm{FYM}+50 \% \mathrm{~N}+\mathrm{PK}$, Azotobacter $+\mathrm{FYM}+75 \% \mathrm{~N}+\mathrm{PK}$. Among the tested treatments, $\mathrm{T}_{7}$ (Azotobacter $+\mathrm{FYM}+75 \% \mathrm{~N}+\mathrm{PK}$ ) recorded the maximum plant height $(66.18 \mathrm{~cm})$, number of primary branches (8.20) and fruit yield (18.08 kg) per plot.
\end{abstract}

Key words: Productivity, primary branches, organic matter, pericarp

\section{Introduction}

Bell pepper (Capsicum annuum L.), member of family Solanaceae is one of the most important vegetable crops grown extensively in sub-temperate climate throughout the world. The environmental conditions in the mid hills of Nepal are very conducive for producing excellent quality fruits of bell pepper (Bhattarai, 2010). Hills could be the leading supplier of high quality fresh fruits of bell peppers to the plains during summer and rainy seasons which bring lucrative returns to the small and marginal hill farmers (Bhattarai and Poudyal, 2011). But, the productivity of bell pepper in Nepal is still low as compared to China, Japan, India and some European countries. The balanced supply of nutrients and scientific management practices has a potential to increase the productivity of bell pepper.

Application of chemical fertilizers alone can supply only one or two nutrient elements to the crop. On the other hand, supplying only organic inputs can improve soil physical and biological environment but suffers from drawback of low content of plant nutrients. The integrated use of chemical fertilizers, organic manures and biofertilizers hold great promise in securing high level of crop productivity with good quality and also to protect soil health from deterioration and pollution hazards. Therefore, there is a need to develop suitable 
integrated nutrient management technology which will go a long way in building of soil fertility and productivity of bell pepper.

Biofertilizers are the products containing carrier based specialized soil microorganisms. The microorganisms can be free living or symbiotic with plants and fix atmospheric nitrogen which is plentiful available. Application of biofertilizers help in improving number of biological activities of desired microorganisms in soil and helps to improve plant growth, fruit yield, seed yield and quality. Furthermore, biofertilizers are the non-bulky and cheap sources of nutrients and may prove cost effective and eco-friendly supplementation in hill vegetable farming and having capacity to increase 2 to $45 \%$ yield in vegetable crops (Wani, 1994). Amongst biofertilizers, Azotobacter has beneficial effects not only to their nitrogen fixing efficiency but also with their ability to produce anti-bacterial and anti-fungal components and growth regulation (Mahajan et al., 2003). Therefore, the present study was designed to study the integrated use of FYM, biofertilizer, and chemical fertilizers for fruit yield and quality of bell pepper.

\section{Methodology}

An experiment was conducted at Nepal Agricultural Research Council/Horticulture Research Division, Khumaltar in 2067/068. It was laid out in a RBD with three replications. The experiment consisted of the following treatments: $\mathrm{T}_{1}=$ Control $(100 \%$ Recommended NPK); $\mathrm{T}_{2}=$ Azotobacter $+25 \% \mathrm{~N}+\mathrm{PK}$; $\mathrm{T}_{3}=$ Azotobacter $+50 \% \mathrm{~N}+\mathrm{PK} ; \mathrm{T}_{4}=$ Azotobacter + $75 \% \mathrm{~N}+\mathrm{PK} ; \mathrm{T}_{5}=$ Azotobacter + FYM $+25 \% \mathrm{~N}+\mathrm{PK}$; $\mathrm{T}_{6}=$ Azotobacter $+\mathrm{FYM}+50 \% \mathrm{~N}+\mathrm{PK}$ and $\mathrm{T}_{7}=$ Azotobacter + FYM $+75 \% \mathrm{~N}+\mathrm{PK}$. The crop was planted in the month of March in a plot size of $2.40 \mathrm{X}$ 2.25. The seeds of California Wonder cultivar of bell pepper were sown in well prepared nursery beds. All the precautions in raising healthy nursery were observed.

The entire dose of phosphorus and potassium and half dose of nitrogen as per treatment combination per plot was applied before transplanting of seedling by broad casting method which was thoroughly mixed up well with the surface layer of the soil. The remaining dose of nitrogen as per treatment in the form of urea was side dressed after five weeks of transplanting. Azotobacter at the rate of $5 \mathrm{~kg} / \mathrm{ha}$ was applied as soil application. The volume of Azotobacter was increased by mixing with $50 \mathrm{~kg}$ FYM and applied evenly before transplanting at the place where seedlings were to be transplanted. FYM, was applied in soil one week before transplanting of bell pepper seedlings. Five plants were randomly marked for recording the data pertaining to growth and yield related parameters.

\section{Results and Discussion Plant height $(\mathbf{c m})$ and primary branches}

A perusal of data presented in Table 1 revealed that plant height in bell pepper was significantly affected by the treatments in the experiment. Maximum plant height $(66.18 \mathrm{~cm})$ was found with treatment $\mathrm{T}_{7}$ (Azotobacter + FYM $+75 \% \mathrm{~N}+\mathrm{PK})$ which was statistically at par with $\mathrm{T}_{6}$ (Azotobacter $+\mathrm{FYM}+50 \%$ $\mathrm{N}+\mathrm{PK})$. Minimum plant height $(53.63 \mathrm{~cm})$ was observed in the plants receiving Azotobacter $+25 \% \mathrm{~N}$ + PK. Similarly, the data depicted in Table 1 also revealed that the soil application of Azotobacter and FYM has significantly affected the number of primary branches. Maximum number of primary branches (8.20) was observed in $\mathrm{T}_{7}$ (Azotobacter $+\mathrm{FYM}+75 \% \mathrm{~N}+$ $\mathrm{PK})$ which was at par with $\mathrm{T}_{6}$ (Azotobacter $+\mathrm{FYM}+$ $50 \% \mathrm{~N}+\mathrm{PK}$ ) and $\mathrm{T}_{4}$ (Azotobacter $\left.+75 \% \mathrm{~N}+\mathrm{PK}\right)$.

Height of the plant is one of the important factors determining yield and harvest duration especially in plants with indeterminate type of growth habit. Taller plants are considered to be more desirable because they lead to more number of branches which ultimately bear more number of fruits and result in increased productivity. In the present study, the maximum plant height and number of primary branches per plant were noticed in $\mathrm{T}_{7}$ (Azotobacter $\left.+\mathrm{FYM}+75 \% \mathrm{~N}+\mathrm{PK}\right)$. It is also interesting to note that the treatments which had FYM application in combination with Azotobacter recorded maximum value with respect to the growth parameters. The treatment $T_{7}$ produced 12.66 per cent taller plants and 11.87 per cent number of primary branches per plant as compared to Control (100\% NPK). 
Dhruba R. Bhattarai et al./Effect of Azotobacter........

Table 1. Effect of Azotobacter and nitrogen levels on plant height and primary branches of bell pepper.

\begin{tabular}{l|c|c}
\hline Treatment & plant height (cm) & $\begin{array}{c}\text { primary branches per } \\
\text { plant }\end{array}$ \\
\hline $\mathbf{T}_{\mathbf{1}}$ Control (100\% recommended NPK) & 58.75 & 7.33 \\
$\mathbf{T}_{\mathbf{2}}$ Azotobacter + 25\% N + PK & 53.68 & 7.20 \\
$\mathbf{T}_{3}$ Azotobacter + 50\%N + PK & 57.43 & 7.26 \\
$\mathbf{T}_{\mathbf{4}}$ Azotobacter + 75\% N + PK & 59.49 & 8.04 \\
$\mathbf{T}_{5}$ Azotobacter + FYM + 25\%N + PK & 57.78 & 7.33 \\
$\mathbf{T}_{\mathbf{6}}$ Azotobacter + FYM+ 50\% N + PK & 62.13 & 8.05 \\
$\mathbf{T}_{7}$ Azotobacter + FYM+ 75\% N + PK & 66.18 & 8.20 \\
$\mathrm{~F}_{-\mathrm{value}}$ & $* *$ & $*$ \\
$\mathrm{CD}_{0.05}$ & 4.53 & 0.54 \\
\hline
\end{tabular}

The possible reason for maximum values in this treatment might be due to the tremendous increase in microbial population due to decomposition of organic matter with the subsequent release of available nutrients to the plants for growth. FYM and Azotobacter applied with inorganic fertilizers improved the effectiveness of chemical fertilizers. Application of Azotobacter helps in improving number of biological activities of desired microorganisms in soil and improves growth of bell pepper plants. These findings are in conformity with Jackson et al. (1964), Mondal et al. (2003) and Poinkar et al. (2006). Similar results were also reported by Ghosh and Das (1998) who recorded maximum shoots per plant with the application of Azotobacter.

Table 2. Effect of Azotobacter and nitrogen levels on number of fruits per plant, fruit yield per plant and fruit yield per plot.

\begin{tabular}{l|c|c|c}
\hline Treatment & $\begin{array}{l}\text { Number of fruits } \\
\text { per plant }\end{array}$ & $\begin{array}{c}\text { Fruit yield per } \\
\text { plant (g) }\end{array}$ & $\begin{array}{l}\text { Fruit yield per } \\
\text { plot (kg) }\end{array}$ \\
\hline $\mathbf{T}_{\mathbf{1}}$ Control (100\% recommended NPK) & 11.56 & 590.02 & 11.80 \\
$\mathbf{T}_{\mathbf{2}}$ Azotobacter + 25\% N + PK & 6.45 & 313.28 & 6.27 \\
$\mathbf{T}_{3}$ Azotobacter + 50\%N + PK & 10.52 & 577.86 & 11.56 \\
$\mathbf{T}_{\mathbf{4}}$ Azotobacter + 75\% N + PK & 11.85 & 648.55 & 12.97 \\
$\mathbf{T}_{5}$ Azotobacter + FYM + 25\%N + PK & 10.21 & 537.05 & 10.74 \\
$\mathbf{T}_{\mathbf{6}}$ Azotobacter + FYM+ 50\% N + PK & 12.14 & 757.54 & 15.15 \\
$\mathbf{T}_{7}$ Azotobacter + FYM+ 75\% N + PK & 13.89 & 903.82 & 18.08 \\
$\mathrm{~F}_{\text {-value }}$ & $* *$ & $* *$ & $* *$ \\
$\mathrm{CD}_{0.05}$ & 2.17 & 66.22 & 1.40 \\
\hline
\end{tabular}

\section{Number of fruits per plant}

The main objective of cultivation of a crop is to have maximum marketable yield for better returns. Amongst the yield contributing parameters the number of fruits per plant is of special importance which contributes a lot in having maximum yield per plant. An examination of Table 2 indicated that number of fruits per plant also influenced significantly with the treatments under investigation. Highest number of fruits per plant (13.89) were recorded with the use of Azotobacter, FYM along with $75 \% \mathrm{~N}+\mathrm{PK}\left(\mathrm{T}_{7}\right)$. The lowest number of fruits per plant (6.45) were recorded in $\mathrm{T}_{2}$ (Azotobacter $+50 \% \mathrm{~N}$ $+\mathrm{PK})$. When $\mathrm{T}_{7}$ was compared with Control (100\% recommended NPK) it was found that this treatment has 20.15 per cent number of fruits per plant.

\section{Fruit yield per plant (g) and per plot}

It is evident from the data Table 2 that the treatments significantly influenced the fruit yield per plant. Maximum fruit yield (903.82 g) was recorded in 
$\mathrm{T}_{7}$ (Azotobacter $+\mathrm{FYM}+75 \% \mathrm{~N}+\mathrm{PK}$. Minimum yield (313.28g) was found in $\mathrm{T}_{2}$ (Azotobacter $+25 \% \mathrm{~N}+$ $\mathrm{PK})$. It can be noted here that $\mathrm{T}_{7}$ treatment recorded 53.18 per cent higher fruit yield as compared to Control (100\% NPK). Similar trends were observed for fruit yield per plot (Table 2). Superimposition of FYM and Azotobacter over the inorganic fertilizers had a spectacular effect on the crop yield which was higher as compared to other treatments. This increase in yield with FYM, Azotobacter and NPK could be attributed to improve vegetative growth, better availability of nutrients at vital growth period and greater synthesis of carbohydrates and their translocation. Moreover FYM also supplied additional nutrients and improved in soil physical properties, which led to better soil physical health. The higher yield of crop due to inorganic and organic combinations may be attributed to the balanced $\mathrm{C} / \mathrm{N}$ ratio. Thus among the treatments tried $\mathrm{T}_{7}$ ( Azotobacter FYM $+75 \% \mathrm{~N}+\mathrm{PK}$ ) proved superior due to difference in mineralization, availability and utilization of nutrients by the plants. Similar findings were reported by Pandey and Kumar (1989) and Narayanamma et al. (2005) while Dass et al. (2008) noticed that use of compost $+50 \%$ recommended chemical fertilizers gave significantly higher yield of bell pepper over $100 \%$ recommended chemical fertilizers.

\section{Fruit size $\left(\mathbf{m m}^{2}\right)$}

It was revealed from the data presented in Table 3 that the effect of different treatments on fruit size was statistically significant. The maximum fruit size $\left(5200.86 \mathrm{~mm}^{2}\right)$ was recorded in the $\mathrm{T}_{7}$ (Azotobacter + FYM + $75 \% \mathrm{~N}+\mathrm{PK}$ ) and minimum fruit size (3963.66 $\left.\mathrm{mm}^{2}\right)$ was in $\mathrm{T}_{5}($ Azotobacter $+\mathrm{FYM}+25 \% \mathrm{~N}+\mathrm{PK})$.

The effect of Azotobacter, FYM registered a noticeable increase in fruit size. However, the effect was much pronounced when integrated application was adopted.

Table 3. Effect of Azotobacter and nitrogen levels on fruit size, fruit weight and pericarp thickness.

\begin{tabular}{l|c|c|c}
\hline Treatment & $\begin{array}{l}\text { Fruit size } \\
\mathbf{m m}^{\mathbf{2}} \mathbf{)}\end{array}$ & $\begin{array}{l}\text { Fruit weight } \\
\text { (g) }\end{array}$ & $\begin{array}{l}\text { Pericarp } \\
\text { thickness (mm) }\end{array}$ \\
\hline $\mathbf{T}_{\mathbf{1}}$ Control (100\% recommended NPK) & 4627.71 & 51.04 & 4.24 \\
$\mathbf{T}_{\mathbf{2}}$ Azotobacter + 25\% N + PK & 4362.45 & 48.57 & 4.14 \\
$\mathbf{T}_{\mathbf{3}}$ Azotobacter + 50\%N + PK & 4591.11 & 54.93 & 4.52 \\
$\mathbf{T}_{\mathbf{4}}$ Azotobacter + 75\% N + PK & 4477.78 & 54.73 & 4.80 \\
$\mathbf{T}_{\mathbf{5}}$ Azotobacter + FYM + 25\%N + PK & 3963.66 & 52.60 & 4.30 \\
$\mathbf{T}_{\mathbf{6}}$ Azotobacter + FYM+ 50\% N + PK & 4549.22 & 62.40 & 5.81 \\
$\mathbf{T}_{7}$ Azotobacter + FYM+ 75\% N + PK & 5200.86 & 65.07 & 6.13 \\
F-value & $* *$ & $* *$ & $*$ \\
CD & 665.38 & 2.32 & 0.23 \\
\hline
\end{tabular}

\section{Fruit weight (g)}

A perusal of data in Table 3 depicted that the different treatments tried resulted significant variation with respect to fruit weight. Maximum individual fruit weight (65.07g) was recorded in $\mathrm{T}_{7}$ (Azotobacter + FYM $+75 \% \mathrm{~N}+\mathrm{PK}$ ) which was statistically at par with $\mathrm{T}_{6}$ (Azotobacter + FYM + 50\% N + PK).

Minimum fruit weight (48.57g) in $\mathrm{T}_{2}$ (Azotobacter + $25 \% \mathrm{~N}+\mathrm{PK})$. It was also noticed that $\mathrm{T}_{7}$ had $27.49 \mathrm{per}$ cent higher fruit weight in comparison to Control (100\% NPK).

\section{Pericarp thickness (mm)}

A significant response of different treatments was recorded on the pericarp thickness of bell pepper fruits.
The highest pericarp thickness (6.20 mm) was recorded in $\mathrm{T}_{7}$ (Azotobacter $\left.+\mathrm{FYM}+75 \% \mathrm{~N}+\mathrm{PK}\right)$ this was statistically at par with $\mathrm{T}_{6}$ (Azotobacter $+\mathrm{FYM}+50 \%$ $\mathrm{N}+\mathrm{PK})$. Lowest value $(4.14 \mathrm{~mm})$ in respect of this trait was noticed in $\mathrm{T}_{2}$ (Table 3 ).

Thick fleshed and medium sized bell pepper fruits (50$80 \mathrm{~g}$ ) are preferred under Nepalese condition. Integrated nutrient management in bell pepper can improve the fruit size and pericarp thickness. Similar opinions have been conferred by various workers, when they applied NPK fertilizers in combination with Azotobacter and compost (Dass et al., 2008; Srivastava et al., 2009 and Bairwa et al., 2009). 
Dhruba R. Bhattarai et al./Effect of Azotobacter........

Integrated approach of Azotobacter, FYM and 75\% N + PK perform better with respect to growth and developmental characters (plant height and number of primary branches), yield and yield attributing characters (number of fruits per plant, fruit yield per plot); fruit quality parameters (fruit weight, fruit size and pericarp thickness). Therefore, on the basis of the results obtained in present study, integrated application of Azotobacter, FYM and 75\% N + PK can be recommended for maximum yield and quality of bell pepper.

\section{References}

Bairawa, H.L., L.N. Mahawer, A.K. Shukla, R.A. Kaushik and S.R. Mathur. 2009. Response of integrated nutrient management on growth yield and quality of okra. Indian Journal of Agricultural Sciences, 79 (5): 381-384

Bhattarai, D.R. and K.P. Poudyal. 2011. Bhede Khursani Kheti Pravidhi. Horticulture Research Division, Nepal Agricultural Research Council, Khumaltar, Lalitpur, Nepal.

Bhattarai, D.R. 2010. What is capsicum? Bikash Today. Gramin Bikash Media, Kathmandu, Nepal.

Dass, A., N.K. Lenka, U.S. Patnaik and S. Sudhishri. 2008. Integrated nutrient management for production, economics and soil improvement in winter vegetables. International Journal of Vegetable Science, 14(2): 104-120
Ghosh, D.C. and A.K. Das. 1998. Effect of biofertilizers and growth regulators on growth and productivity of potato (Solanum tuberosum L.). Indian Agriculturist, 42(2):109.

Jackson, R.M., M.E. Brown and S.K. Burlinghum. 1964. Effects on tomato plant off Azotobacter application. Nature, 192: 575

Mahajan, A., A.K. Choudhary, R.C. Jaggi and R.K. Dogra. 2003. Importance of bio-fertilizers in sustainable agriculture. Farmers' Forum, April, 2003.

Mandal, T., P. Ghanti, B. Mahato, A.R. Mandal, and U. Thapa. 2003. Effect of spacing and biofertilizer on yield and yield attributes of direct sown chilli (Capsicum annuum L. cv Bona Lanka). Environmentand-Ecology, 21(3): 712-715

Narayanamma, M., C.H. Chiranjeevi, I.P. Reddy and S.R. Ahmed. 2005. Integrated nutrient management in cauliflower (Brassica oleracea var. botrytis L.). Vegetable Science, 32(1): 62-64.

Pandey, A. and S. Kumar. 1989. Potential of Azotobacter and Azospirillum as biofertilizers for upland agriculture: a review. Journal of Scientific and Industrial Research, 48(3): 134-144.

Poinkar, M., R.Z. Shembekar, C. Neha, N. Bhaladhare, A. Khewale and K. Dongarkar. 2006. Effect of organic manure and biofertilizers on growth and yield of turmeric (Curcuma longa L.). Journal of Soils and Crops, 16(2): 417-420.

Srivastava, B.K., M.P. Singh, S. Singh, S. Lata, P. Srivastava and U.P. Shahi. 2009. Effect of integrated nutrient management on the performance of crop under brinjalpea-okra cropping system. Indian Journal of Agricultural Sciences, 79 (2): 91-95.

Wani, S.P. 1994. Role of biofertilizers in upland crop production. Ed: HLS Tandon . Fertilizers, organic manures recyclable wastes and biofertilizers. Fertilizer development and consultation organization, New Delhi, India. pp 97-98. 
Nepal Journal of Science and Technology 12 (2011) 29-34 